Check for updates

Cite this: RSC Adv., 2019, 9, 38407

Received 3rd October 2019

Accepted 13th November 2019

DOI: $10.1039 / c 9 r a 08023 f$

rsc.li/rsc-advances

\section{Concise synthesis of 3-alkylthieno[3,2-b] thiophenes; building blocks for organic electronic and optoelectronic materials $\uparrow$}

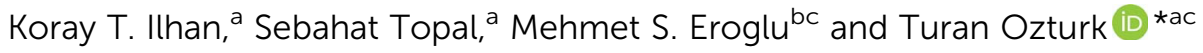

Four step synthesis of 3-alkylthieno[3,2-b]thiophenes in the literature was reduced to two steps in good yields, through the preparation of the mono ketone, i.e. 1-(thiophene-3-ylthio)alkan-2-one, from 3bromothiophene and ring formation reaction. This convenient method provides an easy access with good yields to the preparation of 3-alkylthieno[3,2-b]thiophenes, which are important materials for organic electronic and optoelectronic applications. SEM, AFM and contact angle (CA) analyses of their electropolymers on indium tin oxide (ITO) indicated that as the alkyl chains became longer, the polymers provide a more hydrophobic layer with CA up to $107^{\circ}$
\end{abstract}

\section{Introduction}

Conjugated organic materials are the focus of intense research due to their use as organic semiconductors, which find applications as transistors, solar cells, organic light emitting diodes (OLED), etc. ${ }^{1}$ Compared with their silicon counterparts, as they can be deposited faster from solution during device fabrication, including over large areas, they have significant advantages in terms of time and cost. ${ }^{2}$ Stability of the organic material to oxidation is a necessary criterion as oxidation can diminish device performance. ${ }^{3}$

Various important organic materials in this area are made of thiophene based compounds, ${ }^{4}$ which represent thermally and environmentally stable organic materials for electronic and optoelectronic applications. ${ }^{3,4 c}$ Fused thiophenes play important role in designing building blocks for polymers and small molecules. ${ }^{5}$ Thieno[3,2- $\left.b\right]$ thiophene (TT) is among the widely used fused thiophenes, possessing two fused thiophene units. Thienothiophenes, in general, have four isomers formed through the orientations of the sulfur atoms of the thiophene rings, among which thieno[3,2- $b]$ thiophene belongs to the most widely used TTs as it provides continuous conjugation through two fused thiophenes and polymer backbone. Moreover, presence of two sulfur atoms makes them electron-rich, enabling to be used as electron donating moieties in construction of semiconductors. ${ }^{5}$

${ }^{a}$ Chemistry Department, Istanbul Technical University, Istanbul, Turkey. E-mail: ozturktur@itu.edu.tr

${ }^{b}$ Chemical Engineering, Marmara University, Istanbul, Turkey ${ }^{c}$ Chemistry Group Laboratories, TUBITAK UME, Gebze, Kocaeli, Turkey

$\dagger$ Electronic supplementary information (ESI) available. See DOI: 10.1039/c9ra08023f
In spite of great achievements, preparation of organic materials, particularly polymers and the molecules having fused aromatic systems with desired electronic/optoelectronic properties and soluble in common organic solvents, is still a challenge. It appears that (i) involvement of flat and fused electron rich moieties into the designed molecules to tune their electronic/optoelectronic properties and (ii) providing solubility to the designed molecules are among the important topics. As TTs have flat structures with extended $\pi$-conjugation, they are among highly desirable compounds for tuning band gaps of organic materials and increasing their intermolecular interactions in solid state. ${ }^{5 a, e}$ Thus, involvement of TT in designing organic materials helps tuning organic electronic/optoelectronic materials. Regarding the solubility of the materials, it is mainly provided by pendant alkyl groups on the backbone. Besides, the alkyl groups through their positions on the compound can also provide control on regularity and packing, for which 3-hexylthiophene is widely applied. ${ }^{6}$ Although TTs having alkyl chains are highly desired
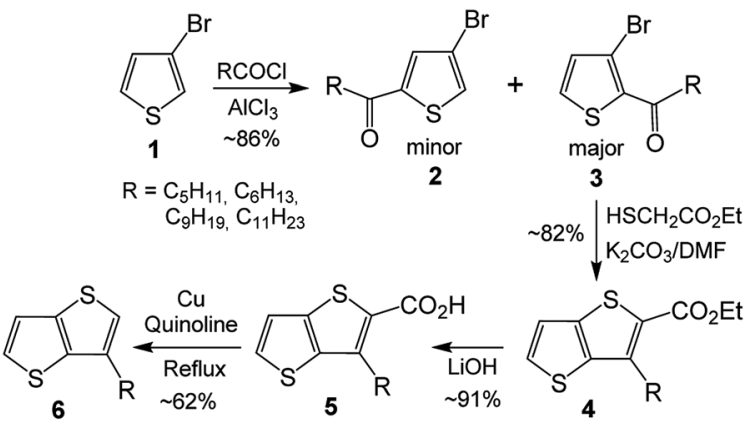

Total yield $=\sim 50 \%$

Scheme 1 The literature synthesis of 3-alkyl-TTs. 
<smiles>[Te]c1ccsc1I</smiles>
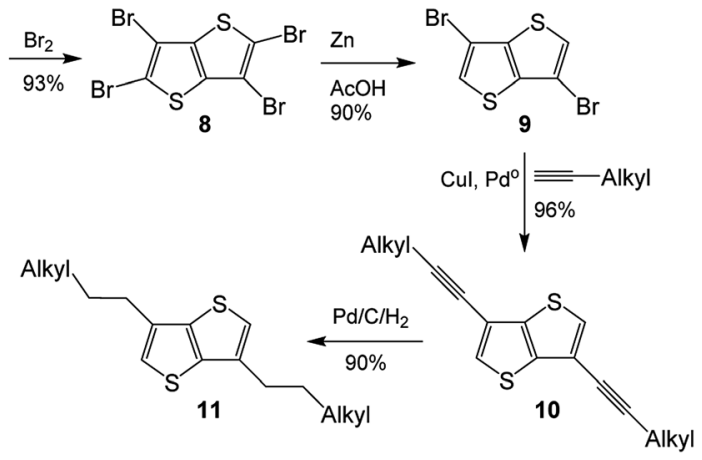

Scheme 2 The literature synthesis of dialkyl- $\pi$. $^{8}$

molecules, providing both (i) flat and fused thiophenes and (ii) alkyl chains on the same molecule, their applications are not as wide as 3-hexylthiophene. One of the important reasons is their cumbersome four step synthesis. ${ }^{7-11}$ It involves FriedelCrafts acylation of 3-bromothiophene 1, which can give a mixture of isomers 2 and 3 as minor and major products, respectively (Scheme 1). ${ }^{7 g}$ Treatment of the major product 3 with ethyl thioglycolate in the presence of $\mathrm{NaOH}$ produces 3alkylthieno[3,2- $b]$ thiophene-2-carboxylate $\mathbf{4}$, hydrolysis of which with $\mathrm{NaOH}$ yields the corresponding acid 5. In the last step, the acid is decarboxylated to give the desired 3-alkylthieno[3,2-b]thiophene 6 (3-alkyl-TT).
As its methodology could be applied to the synthesis of 3alkyl-TT, synthesis of 3,6-dialkylthieno[3,2-b]thiophene (3,6dialkyl-TT) was depicted in Scheme 2 , which also involved four step synthesis. ${ }^{12}$ Thienothiophene 7 was tetrabrominated with $\mathrm{Br}_{2}$ to obtain tetrabromothieno[3,2- $\left.b\right]$ thiophene 8 , which was converted to 3,6-dibromo-TT 9 by treating it with $\mathrm{Zn}$ in acetic acid. Coupling reaction of $\mathbf{9}$ with 1-alkyne produced 3,6dialkyne-TT 10, hydrogenation reaction of which finally gave 3,6-dialkylthieno[3,2- $b]$ thiophene 11.

In the light of our experience on the syntheses of substituted thienothiophenes (TTs) and dithienothiophenes (DTTs), ${ }^{5 a}$ we decided to employ our ring formation reaction ${ }^{\mathbf{1 3}}$ to the syntheses of 3 -alkylthieno[3,2- $b]$ thiophenes, as thieno[3,2- $b]$ thiophene is the most popular TT among its six isomers due to its better conjugation.

\section{Result and discussion}

\subsection{Synthesis}

The synthesis started with the preparation of the monoketones 14 through one-pot three-step reaction (Scheme 3), i.e. (i) lithiation of 3-bromothiophene $\mathbf{1 2}$ with BuLi, (ii) addition of elemental sulfur and, then, (iii) addition of $\alpha$-haloketone $\mathbf{1 3}$. The yields of the ketones varied between 65-92\%. The next step involved ring closure to obtain the alkyl-TTs 15. Refluxing the mono-ketones $\mathbf{1 4}$ in chlorobenzene in the presence of

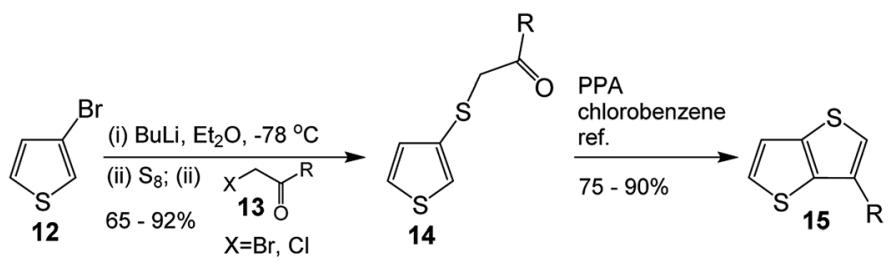

$\mathrm{R}=$ (a) $\mathrm{CH}_{3}$, (b) $\mathrm{C}_{2} \mathrm{H}_{5}$, (c) $\mathrm{C}_{3} \mathrm{H}_{7}$, (d) $\mathrm{C}_{4} \mathrm{H}_{9}$, (e) $i-\mathrm{C}_{5} \mathrm{H}_{11}$,

(f) $n-\mathrm{C}_{5} \mathrm{H}_{11}$, (g) $\mathrm{C}_{6} \mathrm{H}_{13}$,

Total yield $=49-89 \%$

(h) $\mathrm{C}_{7} \mathrm{H}_{15}$, (i) $\mathrm{C}_{8} \mathrm{H}_{17}$,

(j) $\mathrm{C}_{9} \mathrm{H}_{19}$, (k) $\mathrm{C}_{12} \mathrm{H}_{25}$

Scheme 3 Synthesis of 3-alkyl-TTs.

Table 1 Yields of the synthesized and the literature compounds

\begin{tabular}{|c|c|c|c|c|c|}
\hline $\mathrm{R}$ & Ketone (\%) 14 & TT (\%) 15 & Total yield (\%) & Literature yield (\%) & References \\
\hline \multirow[t]{2}{*}{ Methyl (a) } & 65 & 75 & 49 & 17 & 14 \\
\hline & & & & Yield is not given & $7 g$ and 8 \\
\hline Ethyl (b) & 67 & 78 & 52 & - & - \\
\hline Propyl (c) & 72 & 85 & 61 & Yield is not given & 9 \\
\hline Butyl (d) & 70 & 82 & 60 & - & - \\
\hline iso-pentyl (e) & 75 & 90 & 68 & - & - \\
\hline Pentyl (f) & 73 & 85 & 62 & $\sim 35$ & $7 e$ \\
\hline Hekzyl (g) & 77 & 83 & 64 & 50 & 10 \\
\hline Heptyl (h) & 80 & 77 & 62 & $\sim 50$ & 11 and $7 g$ \\
\hline Octyl (i) & 84 & 79 & 66 & 50 & 12 \\
\hline Nonyl (j) & 92 & 87 & 80 & $\sim 52$ & $7 g$ \\
\hline Undecyl (k) & 80 & 90 & 72 & - & - \\
\hline
\end{tabular}




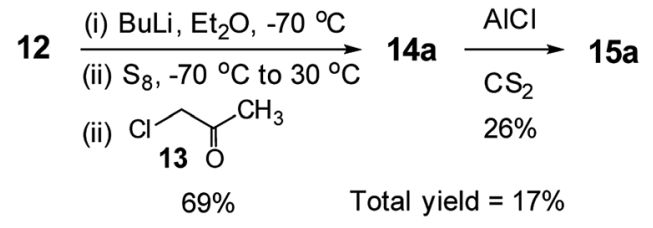

Scheme 4 The literature synthesis of 3-methyl-TT. ${ }^{14}$

polyphosphoric acid (PPA) produced the desired alkyl-TTs between $75-90 \%$ yields. The overall yield for the two-step reaction varied between $49-80 \%$ (Table 3). Compare with the literature total yields, which are around $17-52 \%$, these are very good yields (Table 1). Although the syntheses of TTs with 3-alkyl chains between 5 (15e)-9 (15j) are available in the literature, the TT with a longer alkyl chain of 12 is not available. Besides, the TTs with shorter alkyl chains (15a-15f) either not available or available with lower yields.

Interestingly, the literature synthesis of $\mathbf{1 5 a}$ (Scheme 4$)^{\mathbf{1 4}}$ has some close similarities with the methodology presented in this study. One may think that this study is an extension of the literature one. We honestly declare that this study is a logical extension of our previous studies. ${ }^{1 h, 5 a, 5 b, 13}$ As the literature reaction with a very low total yield was almost hidden in the published manuscript, ${ }^{14}$ we could only be aware of it after the start of this project. While the synthesis of the mono ketone had the same yield with almost the same reaction method, the second step, ring closure reaction, was totally different and with very different yields. The literature reaction was conducted in $\mathrm{CS}_{2}$ using $\mathrm{AlCl}_{3}$, which gave low yield of $26 \%$. The total yield was only $17 \%$. Obviously such reaction condition could not be extended to the synthesis of TTs with various alkyl chains. On the other hand, our ring closure reaction had reaction condition of PPA in refluxing chlorobenzene resulting in higher yield of $75 \%$. As our reaction is simpler and more applicable, it was extended to the synthesis of the TTs with various alkyl chains, even the one having branched alkyl group (15e).

\subsection{Electrochemical studies}

As the 3-alkyl-TTs 15 are in hand and, to our best knowledge, their electropolymerization and UV-CV behaviors were not studied, they were electropolymerized on ITO in $0.1 \mathrm{M} \mathrm{Bu}_{4} \mathrm{PF}_{6} /$ acetonitrile, using Ag and Pt electrodes as reference and counter electrodes, respectively, to obtain the polymers P15a-j. The monomer concentrations were kept at $1 \times 10^{-3} \mathrm{M}$ and the scan rate was $1.0 \mathrm{~V} \mathrm{~s}^{-1}$. Polymerizations of the 3 -alkyl-TTs $\mathbf{1 5 a}-\mathbf{j}$ were

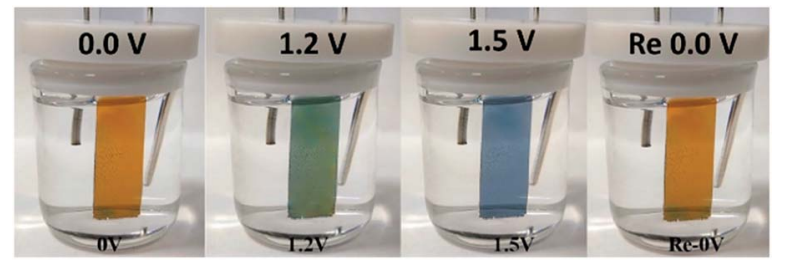

Fig. 1 The color transition of the polymer P15f film coated on ITO at different potentials.
Table 2 Optical data of the polymers

\begin{tabular}{llll}
\hline & $\lambda_{\max }(\mathrm{nm})$ & $\lambda_{\text {onset }}(\mathrm{nm})$ & $E_{\text {gap }}^{\text {Optic }}(\mathrm{eV})$ \\
\hline P15a & 445 & 615 & 2.02 \\
P15b & 391 & 540 & 2.30 \\
P15c & 404 & 605 & 2.05 \\
P15d & 402 & 580 & 2.13 \\
P15e & 413 & 590 & 2.10 \\
P15f & 420 & 625 & 1.98 \\
P15g & 396 & 570 & 2.18 \\
P15h & 393 & 535 & 2.32 \\
P15i & 406 & 645 & 1.92 \\
P15j & 441 & 650 & 1.90
\end{tabular}

observed by means of deposition of the polymers on ITO electrode surface and through the increase of oxidation and reduction peaks (Fig. S1 $\dagger$ ). Their spectroelectrochemistry behaviors were investigated in a monomer-free $\mathrm{CH}_{3} \mathrm{CN}$ solution in the presence of $\mathrm{Bu}_{4} \mathrm{NPF}_{6}$ as a supporting electrolyte (Fig. S2 $\uparrow$ ). The absorbances of the polymers were monitored in situ as a function of potential, ranging from 0.0 to $2.0 \mathrm{~V}$. While the intensity of the $\pi-\pi *$ transitions decreased, an increasing polaron (700-760 nm) and bipolaron (around $1050 \mathrm{~nm}$ ) bands appeared with the increasing potential. They all demonstrated orange-green-blue color changes around $0.0,1.2$ and $1.5 \mathrm{~V}$, respectively. As the polymers demonstrated similar color changes almost at the same potentials, as an example, cyclic voltammetry-ultraviolet-visible (CV-UV) measurement of Pf6 is depicted in Fig. 1.

The polymers had UV-Vis absorption maxima between $390-$ $445 \mathrm{~nm}$, while their monomers had absorptions between 260$270 \mathrm{~nm}$ in solution $\left(\mathrm{CH}_{2} \mathrm{Cl}_{2}\right)$. The optical band gaps varied between 1.90-2.30 eV (Table 2.)

\subsection{Surface analyses}

Surface studies of the polymers by scanning electron microscopy (SEM) and atomic force microscopy (AFM), which were correlated by contact angle (CA) measurements, were then performed, except Pe5, which had a branched alkyl chain (Fig. 2). SEM images were recorded applying two magnifications at $1.000 \times$ and $10.000 \times$ with a scale bars of 50 microns (top row) and 100 microns (bottom row). As evidenced by the higher magnified SEM images, the surfaces had a tendency of becoming more homogeneous with the increasing length of the side chains. While the polymers P15a-P15d had relatively rough surfaces, quasi spherical islets (aggregations), spreading over the scanned area, clearly appeared with the polymers P15f-P15i. These small islets formed a smooth surface with the polymer P15j. AFM-phase (Fig. S3†) and topography images, i.e. the cross-sections along the red lines showing the topographies of the samples (Fig. 2d), indicated that the islets had a different morphology from the polymer matrix, and their root mean square (Rms) values are collected in Table 3. The polymers P15a-P15d had relatively non-homogeneous surface morphology, and, while no apparent trend on their Rms values was observed, a decreasing trend appeared with the polymers 


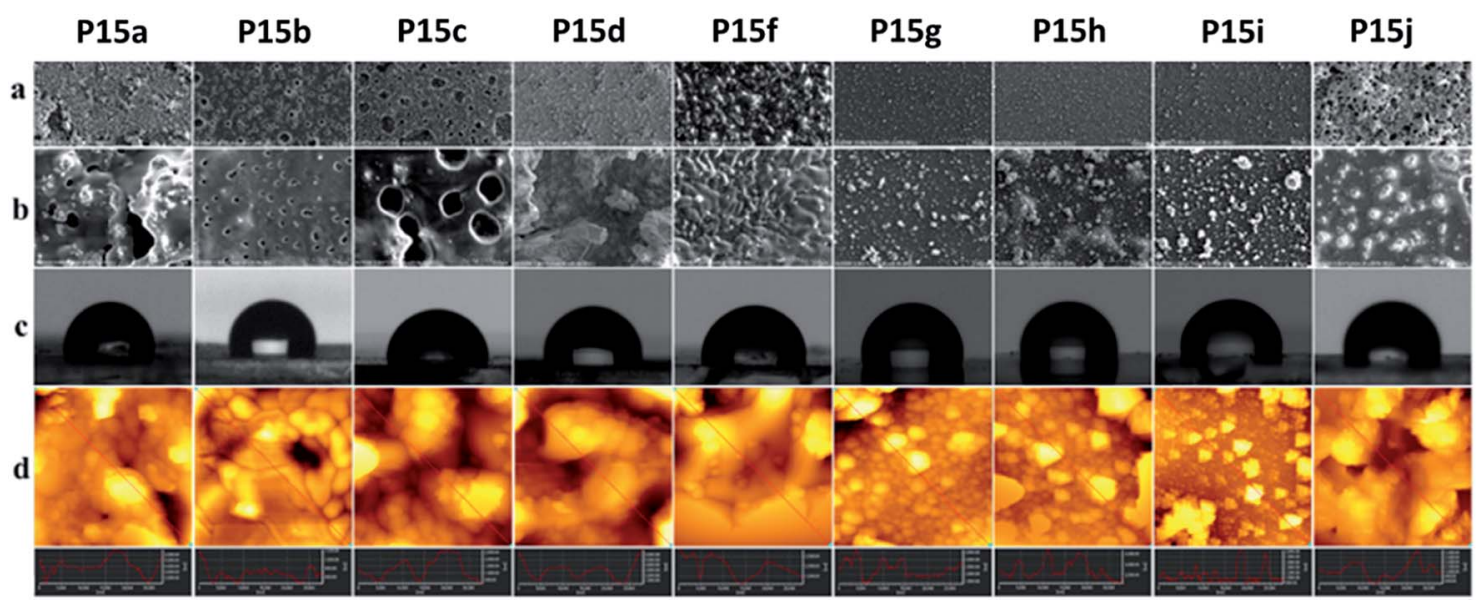

Fig. 2 SEM (a) 1.000x, (b) 10.000x; (c) contact angle, CA; (d) AFM topography images and surface cross section analyses of P15a-P15j.

Table 3 Rms values of the polymers P15a-P15j

\begin{tabular}{lll}
\hline Polymers & Rms $(\mathrm{nm})$ & Water contact angles $\left( \pm 2^{\circ}\right)$ \\
\hline P15a & $1.09 \times 10^{3}$ & 83 \\
P15b & $1.52 \times 10^{2}$ & 84 \\
P15c & $7.13 \times 10^{2}$ & 91 \\
P15d & $1.09 \times 10^{3}$ & 95 \\
P15f & $4.44 \times 10^{2}$ & 97 \\
P15g & $4.34 \times 10^{2}$ & 99 \\
P15h & $4.24 \times 10^{2}$ & 101 \\
P15i & $3.00 \times 10^{2}$ & 102 \\
P15j & $2.98 \times 10^{2}$ & 107
\end{tabular}

P15f-P15j. Moreover, water contact angle studies demonstrated that the surface hydrophobicity of the polymers increased as the length of the lipidic side chains increased. In agreement with the results obtained by SEM, AFM and CA measurements, lipidic side chains were apparently oriented at the surface. Thus, a more homogeneous and highly hydrophobic layer with CA angle up to $107^{\circ}$ (P15j) was formed with the increasing length of the chains. These values are higher than or comparable with the most of the well-known hydrophobic polymers such as polyethylene $\left(96^{\circ}\right)$, polypropylene $\left(102.1^{\circ}\right)$, paraffin $\left(108.9^{\circ}\right)$, etc. $^{15}$

\section{Conclusion}

In conclusion, a convenient synthesis of 3-alkylthieno[3,2-b] thiophenes, important building blocks of various organic materials, with good yields has been developed. This new method reduces the four step cumbersome synthesis available in the literature to a simple two-step synthesis. The two steps, (i) synthesis of mono-ketone and (ii) ring-formation, had the yields between $65-92 \%$ and $75-90 \%$, respectively, with overall yield between $77-90 \%$. This convenient method led to the synthesis of a series of alkyl substituted thienothiophens, varying from 1 to 12 carbons. SEM, AFM and contact angle (CA) analyses of their electropolymers on indium tin oxide (ITO) indicated that, as the carbon chain of the alkyl group increases, lipidic side chains were apparently oriented at the surface, and more homogeneous and highly hydrophobic layer with CA angle up to $107^{\circ}$ was obtained.

\section{Experimental}

\subsection{Materials method}

Cyclic voltammetry (CV) studies were performed using $\mathrm{CH}^{-}$ Instruments Model $400 \mathrm{~A}$ as a potentiostat. UV-Vis measurements were studied on Hitachi U-0080D. ${ }^{1} \mathrm{H}$ and ${ }^{13} \mathrm{C}$ NMR spectra were recorded on Varian model NMR $(500 \mathrm{MHz})$. Proton and carbon chemical shifts were reported in ppm downfield from tetramethylsilane (TMS). Mass spectra were recorded on Bruker MICROTOFQ and Thermo LCQ-Deca ion trap mass instruments.

Scanning Electron Microscopy (SEM) images were recorded to examine the surface morphology of the samples using Hitachi SU 500 FEG-SEM instrument. Images were obtained at 10k and 20k magnifications in the range of $2.0-3.0 \mathrm{kV}$ acceleration voltages, in high vacuum. Surface coating was not applied to samples to observe the morphology in their original form.

Atomic Force Microscopy (AFM) was used to determine the surface topology and morphology of the samples using Hitachi AFM5100N type instrument, which was operated under dynamic mode (DFM). In DFM mode, the tip implements intermittent contact to the sample surface to minimize the destructive lateral forces. Images were obtained by scanning $20 \times 20$ micron area, using SI-DF-3P2 (Hitachi) cantilever with a spring constant of $2.4 \mathrm{~N} \mathrm{~m}^{-1}$ at ambient temperature and humidity.

Contact angle (CA) measurments were conducted to determine the water wettability of the sample surfaces using a Kürüss GmbH DSA-100 model instrument controlled with DS3210 software equipped with direct dosing system and high speed camera. CA measurements were performed using sessile drop technique. At each measurement, $5 \mathrm{~mL}$ of deionized water was placed on the surface. The CA values are average of 5 measurements with a standard deviation of $\pm 3^{\circ}$. 
Spectroelectrochemistry of the polymers was investigated on ITO surface in monomer-free solution using a UV spectroscopy. The polymer coated ITO was placed into a quartz cuvette, filled with monomer-free electrolyte solution for UV-CV measurement. Pt and $\mathrm{Ag}$ wires were used as counter and reference electrodes, respectively. The changes in their absorbance of the polymers were measured in situ as a function of potential change, starting from $0 \mathrm{~V}$, which was gradually increased up to $2.0 \mathrm{~V}$.

\subsection{Synthesis of mono ketones}

1-(Thiophene-3-ylthio)propan-2-one (14a). To a solution of 3bromothiophene 12 (2 g, $12.23 \mathrm{mmol})$ dissolved in dry diethylether $(50 \mathrm{~mL})$ was added $n$-BuLi $(9.25 \mathrm{~mL}, 15.6 \mathrm{mmol}, 1.6 \mathrm{M})$ by syringe at $-78{ }^{\circ} \mathrm{C}$ under nitrogen atmosphere. After stirring the mixture for $50 \mathrm{~min}$, elemental sulfur $(0.41 \mathrm{~g}, 12.8 \mathrm{mmol})$ was added and it was left stirring for $50 \mathrm{~min}$. Then, at the same temperature, chloroacetone $(1.22 \mathrm{~g}, 13 \mathrm{mmol}, 1.05 \mathrm{~mL})$ was added by syringe and the reaction mixture was left stirring at room temperature for overnight. It was extracted with dichloromethane and washed successively with $10 \%$ aqueous $\mathrm{Na}_{2} \mathrm{CO}_{3}$ solution, brine and water, three times each. The organic layer was dried with $\mathrm{Na}_{2} \mathrm{SO}_{4}$, filtered and the solvent was evaporated under reduced pressure. The crude product was purified by column chromatography using a hexane/dichloromethane (10:1) solvent system to give the title compound 14a (1.36 g, $65 \%)$ as a colorless viscose liquid. IR: $1700 \mathrm{~cm}^{-1}(\mathrm{C}=\mathrm{O})$; MS $\mathrm{m} /$ $z: 173\left(\mathrm{M}^{+}+1\right)$. As it was found to be eye irritant, it was not further characterized and directly used for the next step.

The followings were similarly prepared.

1-(Thiophene-3-ylthio)butan-2-one (14b). The crude product was purified by column chromatography using a hexane/ dichloromethane $(10: 1)$ solvent system to give the title compound 14b $(1.52 \mathrm{~g}, 67 \%)$ as a colorless viscose liquid. IR: $1700 \mathrm{~cm}^{-1}$; MS m/z: $185\left(\mathrm{M}^{+}+1\right)$. As it was found to be eye irritant, it was used for the next step without characterization.

1-(Thiophene-3-ylthio)pentan-2-one (14c). The crude product was purified by column chromatography using a hexane/dichloromethane $(10: 1)$ solvent system to give the title compound $14 \mathrm{c}(1.76 \mathrm{~g}, 72 \%)$ as a colorless viscose liquid. IR: $1700 \mathrm{~cm}^{-1}{ }^{1} \mathrm{H}$ NMR $\left(500 \mathrm{MHz}, \mathrm{CDCl}_{3}\right) \delta 7.33(\mathrm{dd}, J=5.0 \mathrm{~Hz}$, $3.0 \mathrm{~Hz}, 1 \mathrm{H}), 7.22(\mathrm{dd}, J=3.0 \mathrm{~Hz}, 1.3 \mathrm{~Hz}, 1 \mathrm{H}), 7.03(\mathrm{dd}, J=5.0 \mathrm{~Hz}$, $1.3 \mathrm{~Hz}, 1 \mathrm{H}), 3.58(\mathrm{~s}, 2 \mathrm{H}), 2.57(\mathrm{t}, J=7.3 \mathrm{~Hz}, 2 \mathrm{H}), 1.60(\mathrm{~m}, 2 \mathrm{H})$, $0.91(\mathrm{t}, J=7.3 \mathrm{~Hz}, 3 \mathrm{H}) ;{ }^{13} \mathrm{C}$ NMR $\left(126 \mathrm{MHz}, \mathrm{CDCl}_{3}\right) \delta$ 205.6, 130.0, 129.6, 126.5, 125.0, 45.0, 42.5, 17.3, 13.7. As it was found to be eye irritant, it was used for the next step without further characterization.

1- (Thiophene-3-ylthio)hexan-2-one (14d). The crude product was purified by column chromatography using a hexane/ dichloromethane $(10: 1)$ solvent system to give the title compound 14d $(1.83 \mathrm{~g}, 70 \%)$ as a colorless viscose liquid. IR: $1700 \mathrm{~cm}^{-1}$; ${ }^{1} \mathrm{H}$ NMR $\left(500 \mathrm{MHz}, \mathrm{CDCl}_{3}\right) \delta 7.33(\mathrm{dd}, J=5.0 \mathrm{~Hz}$, $3.0 \mathrm{~Hz}, 1 \mathrm{H}), 7.22(\mathrm{dd}, J=3.0 \mathrm{~Hz}, 1.3 \mathrm{~Hz}, 1 \mathrm{H}), 7.03(\mathrm{dd}, J=5.0 \mathrm{~Hz}$, $1.3 \mathrm{~Hz}, 1 \mathrm{H}), 3.58$ (s, 2H), 2.58 (t, $J=7.4 \mathrm{~Hz}, 2 \mathrm{H}), 1.56(\mathrm{~m}, 2 \mathrm{H})$, $1.29(\mathrm{~m}, 2 \mathrm{H}), 0.90(\mathrm{t}, J=7.3 \mathrm{~Hz}, 3 \mathrm{H}) ;{ }^{13} \mathrm{C} \mathrm{NMR}\left(126 \mathrm{MHz}, \mathrm{CDCl}_{3}\right)$ $\delta 205.7,129.6,128.7,126.5,125.0,45.0,40.4,25.9,22.2,13.8$. As it was found to be eye irritant, it was used for the next step without further characterization.

5-Methyl-1-(thiophen-3-ylthio)hexan-2-one (14e). The crude product was purified by column chromatography using a hexane/dichloromethane $(10: 1)$ solvent system to give the title compound $14 \mathrm{e}(2.10 \mathrm{~g}, 75 \%)$ as a brown viscose liquid. IR: $1700 \mathrm{~cm}^{-1}$; ${ }^{1} \mathrm{H}$ NMR (500 MHz, $\mathrm{CDCl}_{3}$ ) $\delta 7.33$ (dd, $J=4.9 \mathrm{~Hz}$, $3.1 \mathrm{~Hz}, 1 \mathrm{H}), 7.23(\mathrm{~d}, J=3.1 \mathrm{~Hz}, 1 \mathrm{H}), 7.03(\mathrm{~d}, J=4.9 \mathrm{~Hz}, 1 \mathrm{H}), 3.59$ $(\mathrm{s}, 2 \mathrm{H}), 2.58(\mathrm{t}, J=7.3 \mathrm{~Hz}, 2 \mathrm{H}), 1.46(\mathrm{~m}, J=1.51-1.43,3 \mathrm{H}), 0.88$ $(\mathrm{d}, J=6.4 \mathrm{~Hz}, 6 \mathrm{H})$. As it was found to be eye irritant, it was used for the next step without further characterization.

1-(Thiophene-3-ylthio)heptan-2-one (14f). The crude product was purified by crystallization from hexane to give the title compound $14 f(2.03 \mathrm{~g}, 73 \%)$ as a white powder. $\mathrm{Mp}=41-42{ }^{\circ} \mathrm{C}$; IR: $1700 \mathrm{~cm}^{-1} ;{ }^{1} \mathrm{H}$ NMR (500 MHz, $\left.\mathrm{CDCl}_{3}\right) \delta(\mathrm{ppm}) 7.33(\mathrm{dd}, J=$ $4.9 \mathrm{~Hz}, 3.1 \mathrm{~Hz}, 1 \mathrm{H}), 7.22(\mathrm{dd}, J=2.9 \mathrm{~Hz}, 1.1 \mathrm{~Hz}, 1 \mathrm{H}), 7.03(\mathrm{dd}, J=$ $5.0 \mathrm{~Hz}, 1.0 \mathrm{~Hz}, 1 \mathrm{H}), 3.586(\mathrm{~s}, 2 \mathrm{H}), 2575$ (t, $J=7.4 \mathrm{~Hz}, 2 \mathrm{H}), 1.28$ $(\mathrm{m}, 4 \mathrm{H}), 0.89(\mathrm{t}, J=7.1 \mathrm{~Hz}, 3 \mathrm{H}) ;{ }^{13} \mathrm{C} \mathrm{NMR}\left(126 \mathrm{MHz}, \mathrm{CDCl}_{3}\right)$ $\delta$ 205.7, 130.0, 129.6, 126.5, 125.0, 45.0, 40.6, 31.27, 23.5, 22.4, 13.88. MS $m / z: 229.0\left(\mathrm{M}^{+}+1\right)$.

1-(Thiophene-3-ylthio)octan-2-one (14g). The crude product was purified by crystallization from hexane to give the title compound $14 \mathrm{~g}(2.28 \mathrm{~g}, 77 \%)$ as a white powder. ${ }^{1} \mathrm{H}$ NMR (500 $\left.\mathrm{MHz}, \mathrm{CDCl}_{3}\right) \delta(\mathrm{ppm}) 7.33(\mathrm{dd}, J=5.0 \mathrm{~Hz}, 3.0 \mathrm{~Hz}, 1 \mathrm{H}), 7.22$ (dd, $J$ $=3.0 \mathrm{~Hz}, 1.3 \mathrm{~Hz}, 1 \mathrm{H}), 7.03(\mathrm{dd}, J=5.0 \mathrm{~Hz}, 1.3 \mathrm{~Hz}, 1 \mathrm{H}), 3.58(\mathrm{~s}$, $2 \mathrm{H}), 2.58(\mathrm{t}, J=7.4 \mathrm{~Hz}, 2 \mathrm{H}), 1.57(\mathrm{~m}, 2 \mathrm{H}), 1.28(\mathrm{~m}, 6 \mathrm{H}), 0.88(\mathrm{t}, J$ $=6.9 \mathrm{~Hz}, 3 \mathrm{H}) ;{ }^{13} \mathrm{C} \mathrm{NMR}\left(126 \mathrm{MHz}, \mathrm{CDCl}_{3}\right) \delta 205.7,130.0,129.6$, 126.5, 124.9, 45.0, 40.7, 31.5, 28.8, 23.8, 22.5, 14.0. MS $m / z: 243.0$ $\left(\mathrm{M}^{+}+1\right)$.

1- (Thiophene-3-ylthio)nonan-2-one (14h). The crude product was purified by crystallization from hexane to give the title compound $14 \mathrm{~h}(2.50 \mathrm{~g}, 80 \%)$ as a white powder. $\mathrm{Mp}=58-$ $59{ }^{\circ} \mathrm{C}$; IR: $1700 \mathrm{~cm}^{-1} ;{ }^{1} \mathrm{H}$ NMR $\left(500 \mathrm{MHz}, \mathrm{CDCl}_{3}\right) \delta 7.33(\mathrm{dd}, J=$ $5.0 \mathrm{~Hz}, 1.3 \mathrm{~Hz}, 1 \mathrm{H}), 7.22(\mathrm{dd}, J=3.0 \mathrm{~Hz}, 1.3 \mathrm{~Hz}, 1 \mathrm{H}), 7.03(\mathrm{dd}, J=$ $5.0 \mathrm{~Hz}, 1.3 \mathrm{~Hz}, 1 \mathrm{H}), 3.58$ (s, 2H), 2.57 (t, $J=7.4 \mathrm{~Hz}, 2 \mathrm{H}), 1.57(\mathrm{~m}$, $2 \mathrm{H}), 1.27(\mathrm{~m}, 8 \mathrm{H}), 0.88(\mathrm{t}, J=7.0 \mathrm{~Hz}, 3 \mathrm{H}) ;{ }^{13} \mathrm{C} \mathrm{NMR}(126 \mathrm{MHz}$, $\left.\mathrm{CDCl}_{3}\right) \delta 205.7,130.1,129.6,126.5,125.0,45.0$, 40.7, 31.6, 29.1, 29.0, 23.8, 22.6, 14.1. MS $m / z: 257.0\left(\mathrm{M}^{+}+1\right)$.

1-(Thiophene-3-ylthio)decan-2-one (14i). The crude product was purified by crystallization from hexane to give the title compound $14 \mathbf{i}(2.77 \mathrm{~g}, 84 \%)$ as a white powder. $\mathrm{Mp}=58-60{ }^{\circ} \mathrm{C}$; IR: $1700 \mathrm{~cm}^{-1}$; ${ }^{1} \mathrm{H}$ NMR $\left(500 \mathrm{MHz}, \mathrm{CDCl}_{3}\right) \delta 7.37(\mathrm{dd}, J=5.2 \mathrm{~Hz}$, $1.5 \mathrm{~Hz}, 1 \mathrm{H}), 7.25$ (d, $J=5.2 \mathrm{~Hz}, 1 \mathrm{H}), 7.0(\mathrm{dd}, J=2.3 \mathrm{~Hz}, 1.0 \mathrm{~Hz}$, $1 \mathrm{H}), 2.74(\mathrm{t}, J=7.4 \mathrm{~Hz}, 2 \mathrm{H}), 1.36(\mathrm{~m}, 12 \mathrm{H}), 0.90(\mathrm{t}, J=7.0 \mathrm{~Hz}$, $3 \mathrm{H}) ;{ }^{13} \mathrm{C}$ NMR (126 MHz, $\mathrm{CDCl}_{3}$ ) $\delta$ 205.7, 130.0, 129.6, 126.5, 125.0, 45.0, 40.7, 31.8, 29.3, 29.1, 29.1, 23.8, 22.6, 14.1. MS m/z: $271.2\left(\mathrm{M}^{+}+1\right)$.

1-(Thiophen-3-ylthio)undecan-2-one (14j). The crude product was purified by crystallization from hexane to give the title compound $\mathbf{1 4 j}(3.20 \mathrm{~g}, 92 \%)$ as a white powder. $\mathrm{Mp}=65-66{ }^{\circ} \mathrm{C}$; IR: $1700 \mathrm{~cm}^{-1} ;{ }^{1} \mathrm{H}$ NMR (600 MHz, Acetone-d $\left.{ }_{6}\right) \delta 7.33(\mathrm{dd}, J=$ $5.0 \mathrm{~Hz}, 3.0 \mathrm{~Hz}, 1 \mathrm{H}), 7.22$ (dd, $J=3.0 \mathrm{~Hz}, 1.3 \mathrm{~Hz}, 1 \mathrm{H}), 7.03$ (dd, $J=$ $3.0 \mathrm{~Hz}, 1.3 \mathrm{~Hz}, 1 \mathrm{H}), 3.58$ (s, 2H), 2.57 (t, $J=7.4 \mathrm{~Hz}, 2 \mathrm{H}), 1.56$ (m, $2 \mathrm{H}), 1.26(\mathrm{~m}, 12 \mathrm{H}), 0.89(\mathrm{t}, J=7 . \mathrm{Hz}, 3 \mathrm{H}) ;{ }^{13} \mathrm{C}$ NMR $(150 \mathrm{MHz}$, Acetone- $\left.\mathrm{d}_{6}\right) \delta 205.8,130.0,129.6,126.5,125.0,45.0,40.7,31.8$, 30.9, 29.4, 29.2, 29.1, 23.8, 22.6, 14.1; MS m/z: $285.0\left(\mathrm{M}^{+}+1\right)$. 
1-(Thiophen-3-ylthio)tetradecan-2-one (14k). The crude product was purified by column chromatography using hexane as a solvent to give the title compound 14k $(3.20 \mathrm{~g}, 92 \%)$ as a white powder. $\mathrm{Mp}=72-74{ }^{\circ} \mathrm{C} ;{ }^{1} \mathrm{H}$ NMR (500 $\mathrm{MHz}, \mathrm{CDCl}_{3}$ ) $\delta 7.33(\mathrm{dd}, J=5.0,3.0 \mathrm{~Hz}, 1 \mathrm{H}), 7.22(\mathrm{dd}, J=3.0,1.3 \mathrm{~Hz}, 1 \mathrm{H}), 7.03$ (dd, $J=5.0,1.3 \mathrm{~Hz}, 1 \mathrm{H}), 3.58(\mathrm{~s}, 2 \mathrm{H}), 2.57(\mathrm{t}, J=7.4 \mathrm{~Hz}, 2 \mathrm{H})$, 1.32-1.20 (m, 18H), 0.91-0.85 (m, 5H). ${ }^{13} \mathrm{C}$ NMR (126 MHz, $\left.\mathrm{CDCl}_{3}\right) \delta 205.7,129.5,126.5,125.8,125.4,124.9,124.6,120.7$, 45.0, 40.6, 31.9, 29.6, 29.4, 29.3, 29.1, 23.8, 22.6, 14.1 .

\subsection{Synthesis of TTs}

3-Methylthieno[3,2-b]thiophene (15a). To a hot solution of polyphosphoric acid $\left(135^{\circ} \mathrm{C}, \mathrm{PPA}\right)(5.87 \mathrm{~g})$ was added $14 \mathrm{a}(0.7 \mathrm{~g}$, $0.004 \mathrm{~mol})$ dissolved in chlorobenzene $(5 \mathrm{~mL})$ and the reaction mixture was stirred for $24 \mathrm{~h}$, after which the solvent was evaporated under reduced pressure. It was then extracted successively with dichloromethane, $\mathrm{Na}_{2} \mathrm{CO}_{3}(10 \%)$, brine and water, three times each. Organic layer was dried with sodium sulfate, filtered and the solvent was evaporated under reduced pressure. The crude product was purified by column chromatography using hexane as a solvent to give the title compound $15 \mathrm{a}(0.46 \mathrm{~g}$, $75 \%$ ) as a colorless viscose liquid. ${ }^{1} \mathrm{H}$ NMR (600 $\mathrm{MHz}, \mathrm{CDCl}_{3}$ ) $\delta 7.39(\mathrm{~d}, J=5.2 \mathrm{~Hz}, 1 \mathrm{H}), 7.27(\mathrm{~d}, J=5.1 \mathrm{~Hz}, 1 \mathrm{H}), 7.014(\mathrm{~s}, 1 \mathrm{H})$, $2.410(\mathrm{~s}, 3 \mathrm{H}) ;{ }^{13} \mathrm{C} \mathrm{NMR}\left(150 \mathrm{MHz}, \mathrm{CDCl}_{3}\right) \delta 140.9,138.6,129.6$, 126.7, 122.4, 120.1, 14.9. MS m/z: $155\left(\mathrm{M}^{+}+1\right)$.

The following were similarly prepared.

3-Ethylthieno[3,2-b]thiophenene (15b). The crude product was purified by column chromatography using hexane as a solvent to give the title compound $\mathbf{1 5 b}(0.53 \mathrm{~g}, 78 \%)$ as a colorless viscose liquid. ${ }^{1} \mathrm{H}$ NMR $\left(500 \mathrm{MHz}, \mathrm{CDCl}_{3}\right) \delta 7.38$ (dd, $J=5.2 \mathrm{~Hz}, 1.6 \mathrm{~Hz}, 1 \mathrm{H}), 7.26(\mathrm{~d}, J=5.2 \mathrm{~Hz}, 1 \mathrm{H}), 7.02(\mathrm{~s}, 1 \mathrm{H}), 2.79$ $(\mathrm{m}, 2 \mathrm{H}), 0.91(\mathrm{t}, J=7.0 \mathrm{~Hz}, 3 \mathrm{H}) ;{ }^{13} \mathrm{C} \mathrm{NMR}\left(126 \mathrm{MHz}, \mathrm{CDCl}_{3}\right)$ $\delta 139.8,138.7,136.2,126.6,121.1,119.9,23.1,13.1$. MS $m / z: 169$ $\left(M^{+}+1\right)$. HRESIMS: $M^{+}+1$, found 169.01382. $\mathrm{C}_{8} \mathrm{H}_{9} \mathrm{~S}_{2}$ requires 169.01402.

3-Propylthieno[3,2-b]thiophene (15c). The crude product was purified by column chromatography using hexane as a solvent to give the title compound 15c $(0.62 \mathrm{~g}, 85 \%)$ as a colorless viscose liquid. ${ }^{1} \mathrm{H}$ NMR $\left(500 \mathrm{MHz}, \mathrm{CDCl}_{3}\right) \delta(\mathrm{ppm}) 7.37$ (dd, $J=$ $5.2 \mathrm{~Hz}, 1.5 \mathrm{~Hz}, 1 \mathrm{H}), 7.26(\mathrm{dd}, J=5.2 \mathrm{~Hz}, 1 \mathrm{H}), 7.02(\mathrm{~d}, J=1.1 \mathrm{~Hz}$, $1 \mathrm{H}), 2.73(\mathrm{t}, J=7.2 \mathrm{~Hz}, 2 \mathrm{H}), 1.81(\mathrm{~m}, 2 \mathrm{H}), 1.016(\mathrm{t}, J=7.3 \mathrm{~Hz}$, $3 \mathrm{H}) ;{ }^{13} \mathrm{C}$ NMR $\left(126 \mathrm{MHz}, \mathrm{CDCl}_{3}\right) \delta 139.9,138.7,134.6,126.5$, 121.8, 119.9, 32.0, 21.9, 14.0. MS $m / z: 182\left(\mathrm{M}^{+}\right)$.

3-Butylthieno[3,2-b]thiophene (15d). The crude product was purified by column chromatography using hexane as a solvent to give the title compound $15 \mathbf{d}(0.64 \mathrm{~g}, 82 \%)$ as a colorless viscose liquid. ${ }^{1} \mathrm{H}$ NMR (500 $\left.\mathrm{MHz}, \mathrm{CDCl}_{3}\right) \delta 7.37$ (dd, $J=5.2 \mathrm{~Hz}$, $1.5 \mathrm{~Hz}, 1 \mathrm{H}), 7.26(\mathrm{dd}, J=5.2 \mathrm{~Hz}, 1.5 \mathrm{~Hz}, 1 \mathrm{H}), 7.02(\mathrm{~s}, 1 \mathrm{H}), 2.77$ (t, $J=5.7 \mathrm{~Hz}, 2 \mathrm{H}), 1.78(\mathrm{~m}, 2 \mathrm{H}), 1.45(\mathrm{~m}, 2 \mathrm{H}), 1.00(\mathrm{t}, J=7.3 \mathrm{~Hz}$, $3 \mathrm{H}) ;{ }^{13} \mathrm{C}$ NMR $\left(126 \mathrm{MHz}, \mathrm{CDCl}_{3}\right) \delta 139.9,138.7,134.8,126.5$, 121.7, 119.9, 30.7, 29.6, 22.4, 13.9. MS m/z: $197\left(\mathrm{M}^{+}+1\right)$. HRESIMS: $\mathrm{M}^{+}+1$, found 197.04529. $\mathrm{C}_{10} \mathrm{H}_{13} \mathrm{~S}_{2}$ requires 197.04532 .

3-Isopentylthieno[3,2-b]thiophene (15e). The crude product was purified by column chromatography using hexane as a solvent to give the title compound $15 \mathrm{e}(0.76 \mathrm{~g}, 90 \%)$ as a colorless viscose liquid. ${ }^{1} \mathrm{H}$ NMR $\left(500 \mathrm{MHz}, \mathrm{CDCl}_{3}\right) \delta 7.37(\mathrm{~d}, J$
$=5.2 \mathrm{~Hz} \mathrm{1H}), 7.25(\mathrm{~d}, J=5.2 \mathrm{~Hz}, 1 \mathrm{H}), 7.01(\mathrm{~s}, 1 \mathrm{H}), 2.75(\mathrm{t}, J=$ $5.7 \mathrm{~Hz}, 2 \mathrm{H}), 1.65(\mathrm{~m}, 3 \mathrm{H}), 0.98(\mathrm{~d}, J=5.7 \mathrm{~Hz}, 6 \mathrm{H}) ;{ }^{13} \mathrm{C} \mathrm{NMR}(126$ $\left.\mathrm{MHz}, \mathrm{CDCl}_{3}\right) \delta 139.9,138.7,134.9,126.6,121.6,119.9,37.6$, 27.8, 27.7, 22.5; MS m/z: $211\left(\mathbf{M}^{+}+1\right)$. HRESIMS: $\mathbf{M}^{+}+1$, found 211.06071. $\mathrm{C}_{11} \mathrm{H}_{15} \mathrm{~S}_{2}$ requires 211.06097 .

3-Pentylthieno[3,2-b]thiophene (15f). The crude product was purified by column chromatography using hexane as a solvent to give the title compound $\mathbf{1 5 f}(0.72 \mathrm{~g}, 85 \%)$ as a colorless viscose liquid. ${ }^{1} \mathrm{H}$ NMR $\left(500 \mathrm{MHz}, \mathrm{CDCl}_{3}\right) \delta(\mathrm{ppm}) 7.37$ (dd, $J=$ $5.2 \mathrm{~Hz}, 1.5 \mathrm{~Hz}, 1 \mathrm{H}), 7.26$ (d, $J=5.2 \mathrm{~Hz}, 1 \mathrm{H}), 7.01$ (d, $J=1.5 \mathrm{~Hz}$, $1 \mathrm{H}), 2.75(\mathrm{t}, J=5.7 \mathrm{~Hz}, 2 \mathrm{H}), 1.78(\mathrm{~m}, 2 \mathrm{H}), 1.38(\mathrm{~m}, 4 \mathrm{H}), 0.93(\mathrm{t}, J$ $=7.1 \mathrm{~Hz}, 3 \mathrm{H}) ;{ }^{13} \mathrm{C} \mathrm{NMR}\left(126 \mathrm{MHz}, \mathrm{CDCl}_{3}\right) \delta 140.0,138.7,134.9$, 126.5, 121.7, 119.9, 31.6, 29.9, 28.3, 22.5, 14.0. MS m/z: $212\left(\mathrm{M}^{+}\right)$.

3-Hexylthieno[3,2-b]thiophene (15g). The crude product was purified by column chromatography using hexane as a solvent to give the title compound $\mathbf{1 5 g}(0.74 \mathrm{~g}, 83 \%)$ as a colorless viscose liquid. ${ }^{1} \mathrm{H}$ NMR $\left(500 \mathrm{MHz}, \mathrm{CDCl}_{3}\right) \delta 7.37$ (dd, $J=5.2 \mathrm{~Hz}$, $1.5 \mathrm{~Hz}, 1 \mathrm{H}), 7.25$ (d, $J=5.2 \mathrm{~Hz}, 1 \mathrm{H}), 7.0$ (dd, $J=2.3 \mathrm{~Hz}, 1.0 \mathrm{~Hz}$, $1 \mathrm{H}), 2.74(\mathrm{t}, J=5.7 \mathrm{~Hz}, 2 \mathrm{H}), 1.36(\mathrm{~m}, 8 \mathrm{H}), 0.90(\mathrm{t}, J=7.0 \mathrm{~Hz}, 3 \mathrm{H})$; ${ }^{13} \mathrm{C}$ NMR $\left(126 \mathrm{MHz}, \mathrm{CDCl}_{3}\right) \delta 140.0,138.7,134.9,126.5,121.7$, 119.9, 31.6, 30.0, 29.1, 28.6, 22.6, 14.1; MS m/z $225\left(\mathrm{M}^{+}+1\right)$.

3-Heptylthieno[3,2-b]thiophene (15h). The crude product was purified by column chromatography using hexane as a solvent to give the title compound $\mathbf{1 5 h}(0.73 \mathrm{~g}, 77 \%)$ as a colorless viscose liquid. ${ }^{1} \mathrm{H}$ NMR $\left(500 \mathrm{MHz}, \mathrm{CDCl}_{3}\right) \delta 7.37$ (dd, $J=5.2 \mathrm{~Hz}, 1.3 \mathrm{~Hz}, 1 \mathrm{H}), 7.26(\mathrm{~d}, J=5.2 \mathrm{~Hz}, 1 \mathrm{H}), 7.01$ (d, $J=$ $1.3 \mathrm{~Hz}, 1 \mathrm{H}), 2.75(\mathrm{t}, J=5.7 \mathrm{~Hz}, 2 \mathrm{H}), 1.78(\mathrm{~m}, 2 \mathrm{H}), 1.31(\mathrm{~m}, 8 \mathrm{H})$, $0.90(\mathrm{t}, J=7.0 \mathrm{~Hz}, 3 \mathrm{H}) ;{ }^{13} \mathrm{C} \mathrm{NMR}\left(126 \mathrm{MHz}, \mathrm{CDCl}_{3}\right) \delta 138.7$, 134.9, 126.5, 124.6, 121.7, 119.9, 31.8, 30.0, 29.3, 29.1, 28.6, 22.7, 14.1; MS $m / z 239\left(\mathrm{M}^{+}+1\right)$.

3-Octylthieno[3,2-b]thiophene (15i). The crude product was purified by column chromatography using hexane as a solvent to give the title compound $\mathbf{1 5 i}(0.80 \mathrm{~g}, 79 \%)$ as a colorless viscose liquid. ${ }^{1} \mathrm{H} \mathrm{NMR}\left(500 \mathrm{MHz}, \mathrm{CDCl}_{3}\right) \delta 7.37$ (dd, $J=5.2 \mathrm{~Hz}$, $1.3 \mathrm{~Hz}, 1 \mathrm{H}), 7.25$ (d, $J=5.2 \mathrm{~Hz}, 1 \mathrm{H}), 7.0(\mathrm{~d}, J=1.3 \mathrm{~Hz}, 1 \mathrm{H}), 2.75$ $(\mathrm{t}, J=7.7 \mathrm{~Hz}, 2 \mathrm{H}), 1.77(\mathrm{~m}, 2 \mathrm{H}), 1.32(\mathrm{~m}, 10 \mathrm{H}), 0.89(\mathrm{t}, J=7.0 \mathrm{~Hz}$, $3 \mathrm{H}) ;{ }^{13} \mathrm{C}$ NMR (126 MHz, $\mathrm{CDCl}_{3}$ ) $\delta$ 139.9, 138.7, 134.9, 126.5, 121.7, 119.9, 31.9, 30.0, 29.4, 29.4, 29.2, 28.6, 22.7, 14.1; MS m/z: $253\left(\mathrm{M}^{+}+1\right)$.

3-Nonylthieno[3,2-b]thiophene (15j). The crude product was purified by column chromatography using hexane as a solvent to give the title compound $\mathbf{1 5 j}(0.93 \mathrm{~g}, 87 \%)$ as a colorless viscose liquid. ${ }^{1} \mathrm{H}$ NMR $\left(600 \mathrm{MHz}, \mathrm{CDCl}_{3}\right) \delta 7.37$ (dd, $J=5.3 \mathrm{~Hz}$, $1.3 \mathrm{~Hz}, 1 \mathrm{H}), 7.26(\mathrm{~d}, J=5.3 \mathrm{~Hz}, 1 \mathrm{H}), 7.01(\mathrm{~s}, 1 \mathrm{H}), 2.75(\mathrm{t}, J=$ $7.7 \mathrm{~Hz}, 2 \mathrm{H}), 1.78(\mathrm{~m}, 2 \mathrm{H}), 1.35(\mathrm{~m}, 12 \mathrm{H}), 0.91(\mathrm{t}, J=6.9 \mathrm{~Hz}, 3 \mathrm{H})$; ${ }^{13} \mathrm{C}$ NMR (150 MHz, $\mathrm{CDCl}_{3}$ ) 140.0, 138.7, 134.9, 126.5, 121.7, 119.9, 31.9, 30.0, 29.5 29.4, 29.39, 29.3, 28.6, 22.7, 14.1; MS m/z: $267\left(\mathrm{M}^{+}+1\right)$.

3-Dodecylthieno[3,2-b]thiophene (15k). The crude product was purified by column chromatography using hexane as a solvent to give the title compound 15k (1.11 g, 90\%) as a colorless viscose liquid ${ }^{1} \mathrm{H}$ NMR $\left(500 \mathrm{MHz}, \mathrm{CDCl}_{3}\right) \delta 7.37$ (dd, $J$ $=5.2,1.5 \mathrm{~Hz}, 1 \mathrm{H}), 7.26(\mathrm{~d}, J=5.2 \mathrm{~Hz}, 1 \mathrm{H}), 7.01(\mathrm{~s}, 1 \mathrm{H}), 2.75(\mathrm{t}, J$ $=7.4 \mathrm{~Hz}, 2 \mathrm{H}), 1,81-1.74(\mathrm{~m}, 2 \mathrm{H}), 1.41-1.24(\mathrm{~m}, 18 \mathrm{H}), 0.91(\mathrm{t}, J=$ $6.8 \mathrm{~Hz}, 3 \mathrm{H}) .{ }^{13} \mathrm{C} \mathrm{NMR}\left(126 \mathrm{MHz}, \mathrm{CDCl}_{3}\right) \delta 139.95,138.69,134.89$, 126.53, 121.68, 119.89, 31.93, 29.97, 29.68, 29.66, 29.65, 29.57, 
29.41, 29.38, 29.36, 28.61, 22.70, 14.13. HRESIMS: $\mathrm{M}^{+}+1$, found $309.17025 . \mathrm{C}_{18} \mathrm{H}_{29} \mathrm{~S}_{2}$ requires 309.17052 .

\section{Conflicts of interest}

The authors declare no conflicts of interest.

\section{Acknowledgements}

We thank TUBITAK for supporting this work (216Z041), Istanbul Technical University for grant to KTI (MSc), YOK 100/2000 (ST) and Unsped Global Lojistik, Turkey, for financial support.

\section{References}

1 (a) J. Wang, K. Liu, L. Ma and X. Zhan, Chem. Rev., 2016, 116, 14675-14725; (b) X. Gao and Z. Zhao, Sci. China: Chem., 2015, 58, 947-968; (c) H. Dong, W. Hu and D. Zhu, Chem. Rev., 2012, 112, 2208; (d) A. Facchetti, Chem. Mater., 2011, 23, 733-758; (e) G. Turkoglu, M. E. Cinar and T. Ozturk, Top. Curr. Chem., 2017, 375, 84-129; (f) A. Mishra and P. Bauerle, Angew. Chem., Int. Ed., 2012, 51, 2020-2067; $(g)$ S. Gunes, H. Neugebauer and N. S. Sariciftci, Chem. Rev., 2007, 107, 1324-1338; (h) T. Ozturk, E. Ertas and O. Mert, Tetrahedron, 2005, 61, 11055-11077.

2 A. C. Arias, J. D. MacKenzie, I. McCulloch, J. Rivnay and A. Salleo, Chem. Rev., 2010, 110, 3-24.

3 (a) E. Bundgaard, M. Helgesen, J. E. Carlé, F. C. Krebs and M. Jørgensen, Chem. Phys., 2013, 214, 1546-1558; (b) M. Manceau, E. Bundgaard, J. E. Carlé, O. Hagemann, M. Helgesen, R. Søndergaard, M. Jørgensen and F. C. Krebs, J. Mater. Chem., 2011, 21, 4132-4141.

4 (a) M. Kertesz, C. H. Choi and S. Yang, Chem. Rev., 2005, 105, 3448-3481; (b) I. F. Perepichka and D. F. Perepichka, Handbook of Thiophene-based Materials: Applications in Organic Electronics and Photonics, John Wiley \& Sons, Chichester, UK, 2009; (c) R. McCullough, Adv. Mater., 1998, 10, 93-116; (d) J. Roncali, Chem. Rev., 1997, 97, 173-206.

5 (a) M. E. Cinar and T. Ozturk, Chem. Rev., 2015, 115, 30363140; (b) M. E. Cinar and T. Ozturk, Top. Heterocycl. Chem., 2015, 39, 161-202; (c) P. Kumaresan, S. Vegiraju, Y. Ezhumalai, S. L. Yau, C. Kim, W. Wen-Hsi Lee and M. Chen, Polymers, 2014, 6, 2645-2669; (d) A. C. Arias, J. D. MacKenzie, I. McCulloch, J. Rivnay and A. Salleo, Chem. Rev., 2010, 110, 3-24; (e) P. J. Skabara, in Handbook of thiophene-based materials, ed. I. F. Perepichka and D. F. Perepichka, Wiley, Chichester, 2009, Ch. 3.

6 A. Marrocchi, D. Lanari, A. Facchetti and L. Vaccaro, Energy Environ. Sci., 2012, 5, 8457-8474.

7 (a) Z. Xiao, J. Subbiah, K. Sun, D. J. Jones, A. B. Holmes and W. W. Wong, Polym. Chem., 2014, 5, 6710-6717; (b) X. Wang,
Z. G. Zhang, H. Luo, S. Chen, S. Yu, H. Wang, X. Li, G. Yu and Y. Li, Polym. Chem., 2014, 5, 502-511; (c) Y. Lia, L. Chen, Y. Chen, C. Li, P. Zhang, L. Gao, X. Yang, Y. Tu and X. Zhu, Sol. Energy Mater. Sol. Cells, 2013, 108, 136-145; (d) X. Guo, M. Zhang, L. Huo, F. Xu and Y. Wu, J. Mater. Chem., 2012, 22, 21024-21031; (e) W. Tang, L. Ke, L. Tan, T. Lin, T. Kietzke and Z. Chen, Macromolecules, 2007, 40, 61646171; (f) M. He and F. Zhang, J. Org. Chem., 2007, 72, 442451; (g) X. Zhang, M. Köhler and A. Matzger, Macromolecules, 2004, 37, 6306-6315.

8 H. Liu, F. Wu, B. Zhao, L. Meng, G. Wang, J. Zhang, P. Shen and B. Tan, Dyes Pigm., 2015, 120, 44-51.

9 X. Zong, M. Liang, T. Chen, J. Jia, L. Wang, Z. Sun and S. Xue, Chem. Commun., 2012, 48, 66-6647.

10 J. H. Kim, S. Wood, J. B. Park, J. Wade, M. Song, S. C. Yoon, I. H. J. Jung, J. S. Kim and D. H. Hwang, Adv. Funct. Mater., 2016, 26, 1517-1525.

11 D. Gao, K. Tian, W. Zhang, J. Huang, Z. Chen, Z. Mao and G. Yu, Polym. Chem., 2016, 7, 4046-4052.

12 (a) J. C. Bijleveld, R. A. M. Verstrijden, M. M. Wienk and R. A. J. Janssen, J. Mater. Chem., 2011, 21, 9224; (b) W. Li, Y. Guo, J. Shi, H. Yu, H. Meng, Macromolecules, 49, 72117219.

13 (a) M. E. Cinar, S. T. Cankaya, A. Capan, M. S. Eroglu and T. Ozturk, Eur. Polym. J., 2018, 104, 72-80; (b) I. Osken, O. Sahin, A. S. Gundogan, H. Bildirir, A. Capan, E. Ertas, M. S. Eroglu, J. D. Wallis and T. Ozturk, Tetrahedron, 2012, 68, 1216-1222; (c) A. Capan, H. Veisi, A. C. Goren and T. Ozturk, Macromolecules, 2012, 45, 8228-8236; (d) I. Osken, A. S. Gundogan, E. Tekin, M. S. Eroglu and T. Ozturk, Macromolecules, 2013, 46, 9202-9210; (e) C. Kutahya, A. Allushi, R. Isci, J. Kreutzer, T. Ozturk, G. Yilmaz and Y. Yagci, Macromolecules, 2017, 50, 69036910; (f) T. Ozturk, Tetrahedron Lett., 1996, 37, 2821-2824; (g) E. Ertas and T. Ozturk, J. Chem. Soc., Chem. Commun., 2000, 2039-2040; (h) T. Ozturk, N. Saygili, S. Ozkara, M. Pilkington, C. R. Rice, D. A. Tranter, F. Turksoy and J. D. Wallis, J. Chem. Soc., Perkin Trans. 1, 2001, 1, 407-414; (i) F. Turksoy, J. D. Wallis, U. Tunca and T. Ozturk, Tetrahedron, 2003, 59, 8012-8116; (j) O. Mert, E. Sahin, E. Ertas, T. Ozturk, E. A. Aydin and L. Toppare, J. Electroanal. Chem., 2006, 591, 53-58; (k) G. Turkoglu, M. E. Cinar, A. Buyruk, E. Tekin, S. P. Mucur, K. Kaya and T. Ozturk, J. Mater. Chem. C, 2016, 4, 6045-6053.

14 D. R. Rutherford, J. K. Stille, C. M. Elliott and V. R. Reichert, Macromolecules, 1992, 25, 2294-2306.

15 https:/www.accudynetest.com/polytable_03.html? sortby=contact_angle. 